\title{
Effect of Hydroxyapatite (HAp) Adsorbent Dosage towards Lead Removal
}

\author{
Suhair Omar ${ }^{*}$, Mimi Suliza Muhamad ${ }^{2}$, Lee Te Chuan ${ }^{3}$, Nurul Nadia Rudi ${ }^{1}$, Nuramidah Hamidon ${ }^{2}$, Nor \\ Hazren Abdul Hamid ${ }^{2}$, Hasnida Harun ${ }^{2}$, Norshuhaila Mohamed Sunar ${ }^{2}$, Roslinda Ali ${ }^{2}$ \\ ${ }^{1}$ Department of Civil Engineering Technology, Faculty of Engineering Technology, Universiti Tun Hussein Onn \\ Malaysia, Pagoh Education Hub, 84600 Pagoh, Muar, Johor, Malaysia., suhairomar2015@ gmail.com \\ ${ }^{2}$ Advanced Technology Centre, Faculty of Engineering Technology, Universiti Tun Hussein Onn Malaysia, Pagoh \\ Education Hub, 84600 Pagoh, Muar, Johor, Malaysia. \\ ${ }^{3}$ Department of Production and Operation Management, Faculty of Technology Management and Business, \\ Universiti Tun Hussein Onn Malaysia, 86400 Parit Raja, Batu Pahat, Johor, Malaysia
}

\begin{abstract}
Lead $(\mathrm{Pb})$ is a type of heavy metal that requires removal treatment in the waterworks industry due to its deleterious effects on human health and the ecosystem. In the present work, hydroxyapatite (HAp) nanopowder was successfully developed from Tilapia $s p$. fish scales via chemical heat treatment method. The removal of $\mathrm{Pb}$ in solution was investigated by 1,2 , and $4 \%$ HAp adsorbent dosage. FESEM analysis shows the formation of the nanoporous structure of the adsorbent, while FTIR analysis exhibit the presence of phosphate and hydroxyl groups that contribute to the chemisorption process. EDX analysis confirms the $\mathrm{Ca} / \mathrm{P}$ ratio of 1.96 , which was slightly greater than the stoichiometric ratio of pure HAp at 1.67. XRD analysis reveals sharp diffraction lines that indicate the crystallinity of HAp adsorbent. Batch adsorption experiment recorded maximum $\mathrm{Pb}$ removal at $4 \%$ HAp dosage with $100 \%$ removal in $10 \mathrm{~min}$.
\end{abstract}

Key words: Adsorbent, Adsorption, Fish scale, Hydroxyapatite, Lead.

\section{INTRODUCTION}

The rapid growth of the metallurgy industrial has led to serious environmental problems especially on the contamination of heavy metals. The presence of heavy metals in the ecosystem is mainly caused by various industry activities including mining, paint, pigment, electroplating, textiles, battery manufacturing, pesticides and petroleum refining [1]. Investigation on heavy metals concentration in the agricultural ecosystem near a lead-acid battery factory showed the potential risk to human health as the concentration detected has exceeded the tolerable limit of 0.2 $\mathrm{mg} / \mathrm{kg}$ that may cause a potential threat to the environment and human health [2]. Thus, a low concentration of lead contamination has become a major concern to humans as it is listed as one of the chemicals that can emit high negative effects on the public [3].

Several conventional methods have been applied for the removal of heavy metals like lead such as reverse osmosis, ion exchange, chemical precipitation, and adsorption. Among these, adsorption shows promising results in removing heavy metals from water owing to its effective removal, low cost, flexible, easy to produce and more simple operation [4] [1]. Therefore, many researchers have been studied for the development of adsorbents from waste which may potentially be good for the adsorption process. These include eggshells [5], bovine bones [6], spent coffee grounds [7] and fish scales [8]. This study aims to remove lead in tap water source using Tilapia sp. fish scales as low cost and environmentally friendly adsorbent.

\section{MATERIALS AND METHOD}

\subsection{Preparation of Hap Adsorbent}

Collected Tilapia sp. fish scales from the fish processing industries were synthesized using a chemical heat treatment method to produce hydroxyapatite (HAp) adsorbent [9]. The collected fish scales were firstly washed thoroughly with distilled water to remove any dirt and salts before it was air-dried. Then, the scales were soaked overnight in $0.1 \mathrm{M}$ of hydrochloric acid $(\mathrm{HCl})$ before washed several times with distilled water. The remaining proteins were further treated using $5 \%(\mathrm{w} / \mathrm{v})$ of natrium hydroxide $(\mathrm{NaOH})$ solution followed by constant heating and stirring at $70^{\circ} \mathrm{C}$ for $5 \mathrm{~h}$ until fine white particles of HAp was obtained. The product is then re-washed with distilled water and dried at $60{ }^{\circ} \mathrm{C}$. Adsorbent preparation continues by treating the acquired nanopowder with $50 \%(\mathrm{w} / \mathrm{v}) \mathrm{NaOH}$ and reheated at $100{ }^{\circ} \mathrm{C}$ with constant stirring for another $1 \mathrm{~h}$. Finally, the HAp was washed thoroughly with distilled water until the washing solution reaches neutral $\mathrm{pH}$ prior to drying at $60{ }^{\circ} \mathrm{C}$ in the oven to remove any unwanted moisture. 


\subsection{Adsorbent Characterization}

The HAp nanopowder was characterized by several analyses to investigate its physical and chemical properties. This includes Field Emission Scanning Electron Microscopy (FESEM), Energy Dispersive X-ray Spectroscopy (EDX), Fourier Transform Infrared Spectroscopy (FTIR) and X-ray diffraction (XRD) analysis.

\subsubsection{Field Emission Scanning Electron Microscopy (FESEM) and Energy Dispersive X-ray Spectroscopy (EDX) Analysis}

The morphology and elemental composition of the HAp nanopowder before the adsorption process was characterized through FESEM and EDX analysis. The sample was coated with a thin layer of gold that acts as a conductive coat before the microscopic examination was conducted with a MEGA VIEW-II DOC U digital camera that operates at $20.0 \mathrm{kV}$.

\subsubsection{Fourier Transform Infrared Spectroscopy (FTIR) Analysis}

The surface functionalization of HAp was characterized at 4 $\mathrm{cm}^{-1}$ resolution and frequency ranging between 4000 to 400 $\mathrm{cm}^{-1}$ by FTIR analysis using the Attenuated Total Reflection (ATR) technique. The potassium bromide $(\mathrm{KBr})$ pellet method was used in the sample preparation.

\subsubsection{X-ray Diffraction (XRD) Analysis}

$\mathrm{X}$-ray diffraction analysis was used to analyse the purity of the produced HAp adsorbent. The data was measured by $\mathrm{Cu} \mathrm{K} \alpha$ monochromatic radiation $(\lambda=1.5406 \AA)$. The HAp nanopowder is compressed in the cassette sample holder and the data is collected from $2 \theta=20^{\circ}$ with a scan step of $0.02^{\circ}$.

\subsection{Batch Adsorption Experiment}

The performance of the synthesized HAp nanopowder towards lead removal in solution was conducted via batch adsorption study. Initially, $1000 \mathrm{mg} / \mathrm{L}$ lead $(\mathrm{Pb})$ stock solution was prepared by dissolving $1000 \mathrm{mg} \mathrm{Pb}$ powder (Bendosen) in nitric acid $\left(\mathrm{HNO}_{3}\right)$ and ultrapure water at $350{ }^{\circ} \mathrm{C}$ in $1 \mathrm{~L}$ volumetric flask. Then, the synthetic $\mathrm{Pb}$ solution was diluted to $10 \mathrm{mg} / \mathrm{L}$ by spiked the solution in a $500 \mathrm{~mL}$ conical flask containing ultrapure water and HAp nanopowder at different dosages. HAp adsorbent dosage was varied from 1, 2 and $4 \mathrm{wt}$ $\%$, with a constant $\mathrm{pH}$ of 7 of the tap water. Next, the sample solutions were shaken by orbital shaker at a constant stirring speed of $130 \mathrm{rpm}$ for $60 \mathrm{~min}$ at room temperature. $10 \mathrm{~mL}$ sample solutions were drawn from each flask at a certain time interval prior to the analysis of $\mathrm{Pb}$ concentration using Inductively Coupled Plasma Optical Emission Spectroscopy
(ICP-OES) (PerkinElmer Optima 8000).

The following equation (1) [10] was applied to calculate the removal of $\mathrm{Pb}$ concentration after the adsorption process:

$$
\text { Removal }(\%)=\frac{\left(\mathrm{C}_{0}-\mathrm{C}_{\mathrm{f}}\right)}{\mathrm{C}_{0}} \times 100 \%
$$

Where $\mathrm{C}_{0}$ refers to initial $\mathrm{Pb}$ concentration and $\mathrm{C}_{\mathrm{f}}$ is the final $\mathrm{Pb}$ concentration in the solution. The units are in $\mathrm{mg} / \mathrm{L}$ or ppm.

\section{RESULTS AND DISCUSSION}

\subsection{Adsorbent Characterization}

The nanoporous structure and elemental composition of HAp adsorbent were analysed by FESEM and EDX as shown in Figures 1 and 2, respectively. The white region on the HAp surface represents the inorganic substance in the sample such as $\mathrm{P}$ and $\mathrm{Ca}$, meanwhile dark surface refers to an organic composition that contains high protein due to the presence of $\mathrm{C}$ and $\mathrm{O}$ in the HAp [8]. The purity of HAp can be determined by the $\mathrm{Ca} / \mathrm{P}$ ratio which is considered as pure at a ratio of 1.67 . However, the obtained $\mathrm{Ca} / \mathrm{P}$ ratio in this study is slightly higher which is 1.96. According to Ramesh et al. [11], a higher $\mathrm{Ca} / \mathrm{P}$ ratio will result in the high stability of material towards greater temperature.
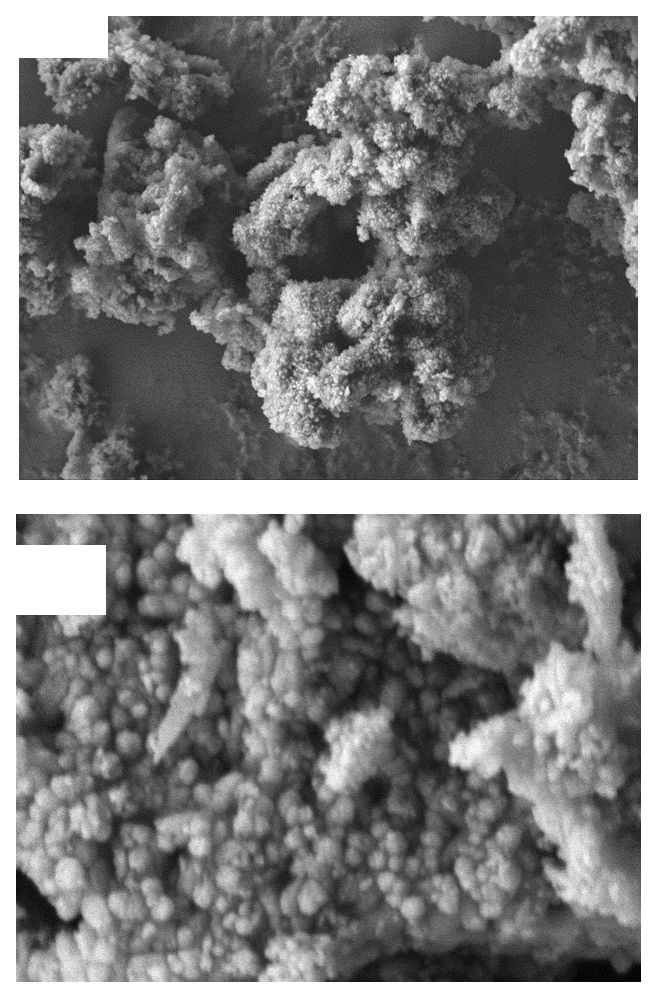

Figure 1: FESEM micrographs of Hap adsorbent at a magnification of (a) 10000 and (b) 50000 


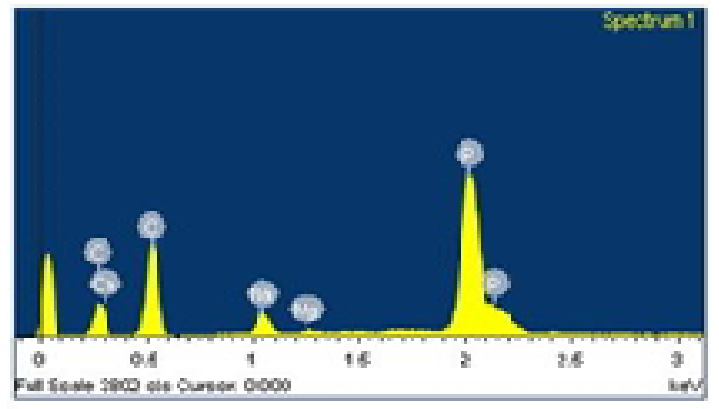

Figure 2: EDX spectrum of HAp nanopowder

The HAp surface functionalization was shown in Figure 3. The stretching at $3246 \mathrm{~cm}^{-1}$ indicates the presence of $\mathrm{OH}^{-}$ group and peaks at $1417 \mathrm{~cm}^{-1}$ showed $\mathrm{C}=\mathrm{C}$ bond. $\mathrm{PO}_{4}{ }^{3-}$ group was represented from the asymmetric stretching mode of vibration at $1018 \mathrm{~cm}^{-1}$. The existence of these anion groups on the adsorbent surface contributes to an efficient adsorption mechanism for lead removal by increasing the number of active sites [12].

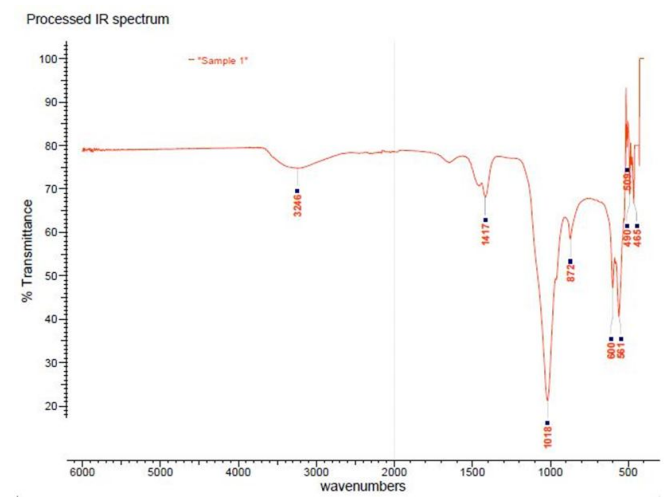

Figure 3: FTIR spectra of HAp

Figure 4 shows the result of the XRD analysis of HAp nanopowder. The obtained peaks showed a relative pattern when compared to the XRD standard of HAp (JDS 00-009-0432). The adsorbent has sharp diffraction lines that indicate the crystallinity of the fish scales [13].

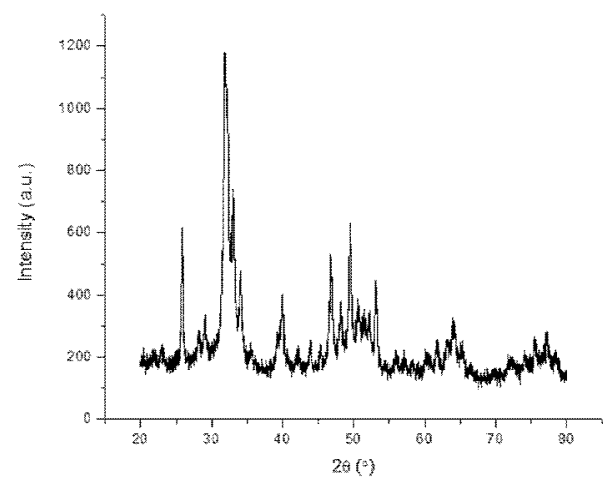

Figure 4: XRD pattern of HAp

\subsection{Batch Adsorption Experiment}

The batch adsorption study by various adsorbent dosages of 1 , 2 and $4 \%$ were conducted at an initial $\mathrm{Pb}$ concentration of 10 $\mathrm{mg} / \mathrm{L}$. Figure 5(a) and (b) show the performance of $1 \%$ HAp adsorbent for removal of $\mathrm{Pb}$ from the solution. The concentration of $\mathrm{Pb}$ was efficiently removed from $99.4 \%$ ( 0.74 $\mathrm{mg} / \mathrm{L})$ at initial to the maximum removal of $100 \%(0.00$ $\mathrm{mg} / \mathrm{L}$ ) after $60 \mathrm{~min}$ of adsorption process.
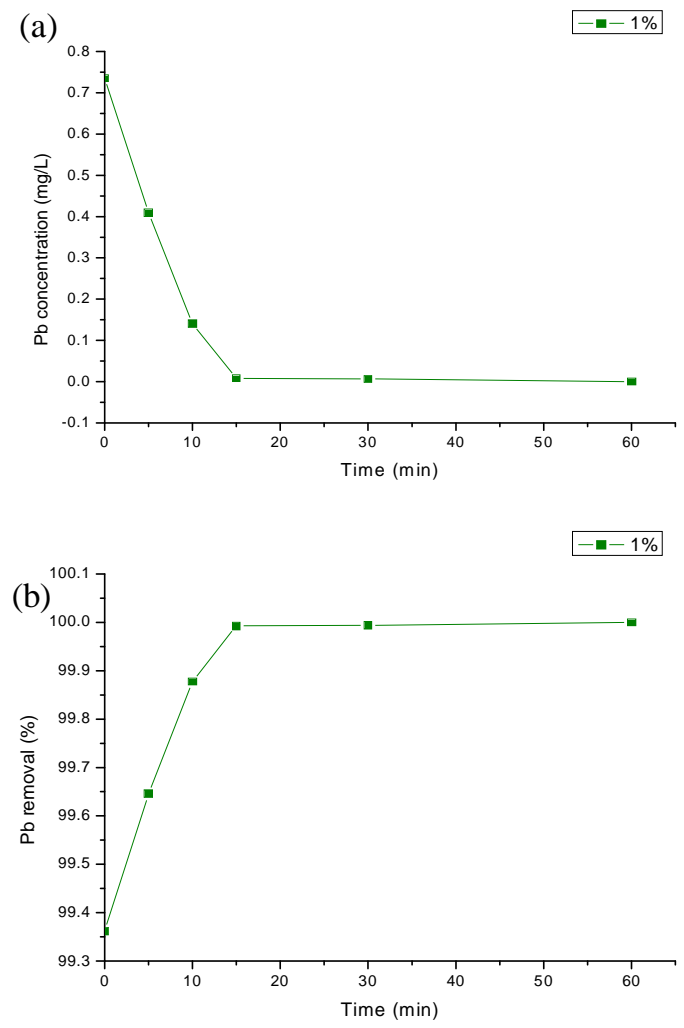

Figure 5: (a) $\mathrm{Pb}$ concentration in free solution against time and (b) $\mathrm{Pb}$ removal rate at $1 \% \mathrm{HAp}$

For the adsorbent dosage of $2 \%$, the $\mathrm{Pb}$ concentration shows the highest reduction of $0.07 \mathrm{mg} / \mathrm{L}$ after $30 \mathrm{~min}$ adsorption process in which the $\mathrm{Pb}$ removal reach $100 \%$ as shown in Figure 6(a) and (b).

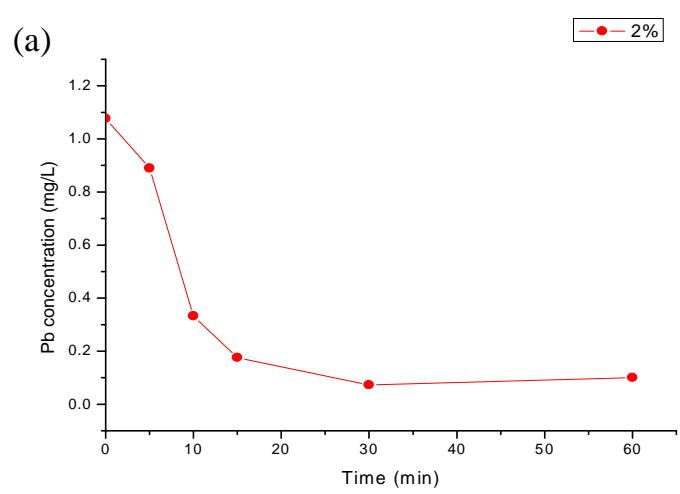




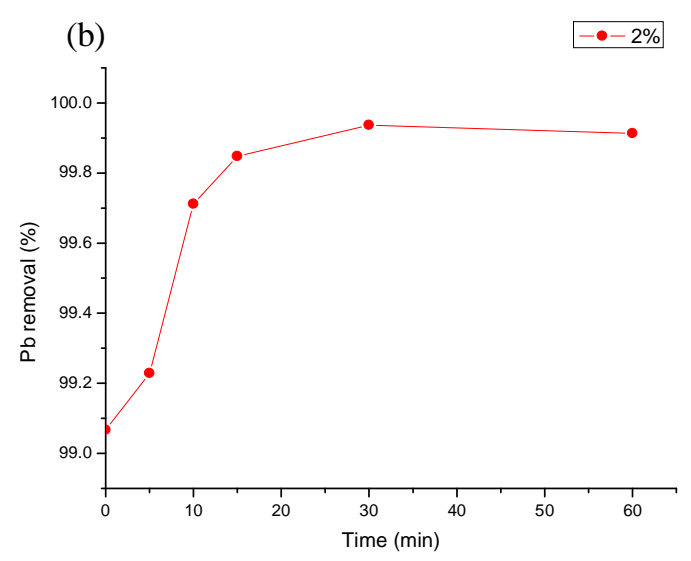

Figure 6: (a) $\mathrm{Pb}$ concentration in free solution against time and (b) $\mathrm{Pb}$ removal rate at $2 \% \mathrm{HAp}$

The $\mathrm{Pb}$ removal was $100 \%$ after 10 min of the adsorption process using 4\% HAp nanopowder as in Figure 7(a) and (b). The concentration of $\mathrm{Pb}$ was significantly removed from $0.327 \mathrm{mg} / \mathrm{L}$ to $0.1 \mathrm{mg} / \mathrm{L}$.

(a)
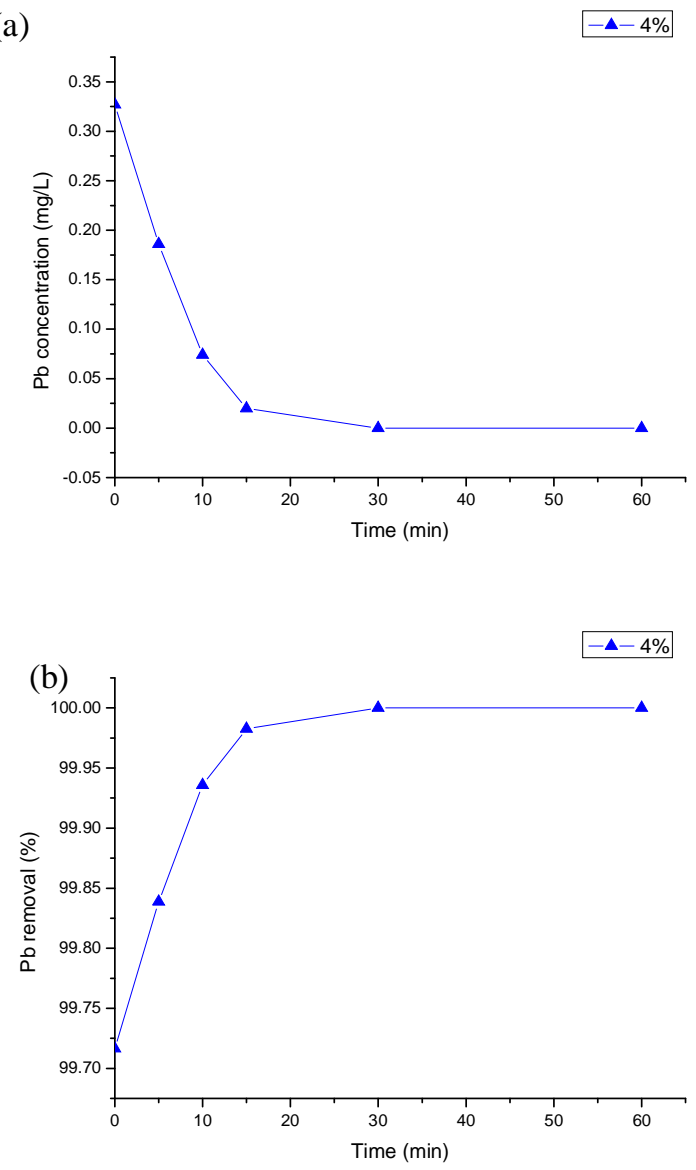

Figure 7: (a) $\mathrm{Pb}$ concentration in free solution against time and (b) $\mathrm{Pb}$ removal rate at $4 \% \mathrm{HAp}$
Based on these findings, there is a correlation between HAp adsorbent dosage towards $\mathrm{Pb}$ removal. The adsorption of $\mathrm{Pb}$ in solution increases with the increase of adsorbent dosage as reported in previous study [14]. This happens due to the increase in active site availability that causing a greater removal rate. According to Aksu et al. [14], higher initial HAp concentration acts as an important driving force to overcome all mass transfer resistances of the $\mathrm{Pb}$ between the solid and aqueous phases, therefore increases the $\mathrm{Pb}$ uptake.

\section{CONCLUSION}

This work revealed that the HAp nanopowder synthesized from Tilapia $s p$. fish scale is a potential adsorbent to be used for the removal of $\mathrm{Pb}$ in aqueous solution. The most efficient adsorbent dosage was attained by $4 \%$ of HAp adsorbent with $100 \% \mathrm{~Pb}$ removal in $10 \mathrm{~min}$ of $\mathrm{pH} 7$. The increase of adsorbent dosage will increase the adsorption process owing to its high active site availability as shown in the HAp nanoporous structure in FESEM analysis. The existence of $\mathrm{PO}_{4}$ and $\mathrm{OH}$ functional groups also contribute to the $\mathrm{Pb}$ adsorption mechanism. The peaks detected in XRD and EDX analysis confirm the crystallinity and $1.96 \mathrm{Ca} / \mathrm{P}$ ratio of the HAp adsorbent, respectively.

\section{ACKNOWLEDGEMENT}

The authors wish to thank Ministry of Higher Education (MOHE), Malaysia for the financial support from Fundamental Research Grant Scheme grant (K219) (FRGS/1/2019/TK10/UTHM/03/3).

\section{REFERENCES}

1. S. Srivastava, S. B. Agrawal, and M. K. Mondal. Animal wastes: an alternative adsorbent for removal of toxic heavy metals from industrial wastewater, J. Sci. Res., vol. 60, no. March 2018, pp. 65-72, 2016.

2. Z. Yang, Z. Fang, P. E. Tsang, J. Fang, and D. Zhao. In situ remediation and phytotoxicity assessment of lead-contaminated soil by biochar-supported nHAP, J. Environ. Manage., vol. 182, pp. 247-251, 2016.

3. World Health Organization, Adverse Health Effects of Heavy Metals in Children, Child. Heal. Environ. WHO Train. Packag. Heal. Sect. World, pp. 1-77, 2011.

4. H. B. Bradl, Adsorption of heavy metal ions on soils and soils constituents, J. Colloid Interface Sci., vol. 277, no. 1, pp. 1-18, 2004.

5. S. Meski, S. Ziani, and H. Khireddine, Removal of lead ions by hydroxyapatite prepared from the egg shell, $J$. Chem. Eng. Data, vol. 55, no. 9, pp. 3923-3928, 2010.

6. J. Brzezińska-Miecznik, K. Haberko, M. Sitarz, M. M. Bućko, and B. Macherzyńska, Hydroxyapatite from animal bones - Extraction and properties, Ceram. Int., vol. 41, no. 3, pp. 4841-4846, 2015.

7. R. Lavecchia, F. Medici, M. S. Patterer, and A. Zuorro, Lead removal from water by adsorption on spent 
coffee grounds, Chem. Eng. Trans., vol. 47, pp. 295-300, 2016.

8. N. Othman, A. Abd-Kadir, and N. Zayadi, Waste fish scale as cost effective adsorbent in removing zinc and ferum ion in wastewater, ARPN J. Eng. Appl. Sci., vol. 11, no. 3, pp. 1584-1592, 2016.

9. S. Kongsri, K. Janpradit, K. Buapa, S. Techawongstien, and S. Chanthai, Nanocrystalline hydroxyapatite from fish scale waste: Preparation, characterization and application for selenium adsorption in aqueous solution, Chem. Eng. J., vol. 215-216, pp. 522-532, 2013.

10. S. M. Mousa, N. S. Ammar, and H. A. Ibrahim, Removal of lead ions using hydroxyapatite nano-material prepared from phosphogypsum waste, J. Saudi Chem. Soc., vol. 20, no. 3, pp. 357-365, 2016.

11. S. Ramesh, C. Tan, M. Hamdi, I. Sopyan, and W. Teng, The influence of $\mathrm{Ca} / \mathrm{P}$ ratio on the properties of hydroxyapatite bioceramics, International Conference on Smart Materials and Nanotechnology in Engineering, vol. 6423, p. 64233A, 2007.

12. S. Omar, M. S. Muhamad, L. Te Chuan, T. Hadibarata, and Z. C. Teh, A Review on Lead Sources, Occurrences, Health Effects and Treatment Using Hydroxyapatite (HAp) Adsorbent Made from Fish Waste, Water Air Soil Pollut., vol. 230, no.12, 2019.

13. I. Zainon, N. M. Alwi, M. Z. Abidin, H. M. Z. Haniza, M. S. Ahmad, and A. Ramli, Physicochemical Properties of Hydroxyapatite Extracted from Fish Scales, $A d v$. Mater. Res., vol. 545, pp. 235-239, 2012.

14. I. Mobasherpour, E. Salahi, and M. Pazouki, Potential of nano crystalline hydroxyapatite for lead (II) removal from aqueous solutions: Thermodynamic and adsorption isotherm study, African J. Pure Appl. Chem., 5, 383-392, 2011.

15. Z. Aksu, and S. Tezer, Biosorption of reactive dyes on the green alga Chlorella vulgaris, Process Biochem., 40 1347-1361, 2005. 